\title{
AFLATOXIN EFFETC ON THE OOCYSTS MORPHOMETRY AND CONTRIBUTION ON THE MORPHOLOGY OF Eimeria bateri BHATIA, PANDEY AND PANDE, 1965 FROM THE JAPANESE QUAIL Coturnix japonica IN BRAZIL
}

\author{
BRUNO P. BERTO ${ }^{1}$; SERGIAN V. CARDOZO²; WALTER L. TEIXEIRA FILHO ${ }^{3}$; ANA MARIA R. FERREIRA ${ }^{4}$; \\ CARLOS WILSON G. LOPES ${ }^{3}$
}

\begin{abstract}
BERTO, B.P.; CARDOZO, S.V.; TEIXEIRA-FILHO, W.L.; FERREIRA, A.M.R.; LOPES, C.W.G. Aflatoxin effect on the oocysts morphometry and contribution on the morphology of Eimeria bateri Bhatia, Pandey and Pande, 1965 of the Japanese quail Coturnix japonica, in Brazil. [Efeito da aflatoxina sobre a morfometria dos oocistos e contribuição para a morfologia de Eimeria bateri Bhatia, Pandey and Pande, 1965 da Codorna japonesa Coturnix japonica no Brasil]. Revista Brasileira de Parasitologia Veterinária, v. 17, n. 4, p. 235-238, 2008. Curso de Pós-Graduação em Ciências Veterinárias, Universidade Federal Rural do Rio de Janeiro, BR-465, km 7, Seropédica, RJ 23890-000, Brasil. E-mail: bertobp@ufrrj.br

The purpose of this study was to characterize Eimeria bateri oocysts and to evaluate the aflatoxin effect in the morphometry of sporulated oocysts in Japanese quails infected naturally. Of a total of 50 quails naturally infected by $E$. bateri were randomly divided into two groups with 25 birds each. In one of them, quails were orally administered with aflatoxin in dose of $0.04 \mathrm{mg} / \mathrm{kg}$ body weight previously. Both experimental groups shed E. bateri oocysts. These oocysts were subspherical to ellipsoidal, $25.1 \times 18.9 \mu \mathrm{m}$, with bi-layered wall. Micropyle and residuum were absent, but one or more polar granules were present. Sporocysts elongate ovoid, $12.5 \times 7.4 \mu \mathrm{m}$. Stieda and substieda bodies were present. Sporocyst residuum was dispersed and sporozoites presented a nucleus and a refractile body. Histograms confirmed the presence of a single species, E. bateri. Linear regression proved that E. bateri oocysts are polymorphic, due, basically, to shape of these oocysts. The comparative morphometry between two experimental groups demonstrated that the aflatoxin influenced significantly in the E. bateri oocysts.
\end{abstract}

KEY WORDS: Coccidia, sporulated oocysts, comparative morphometry, Eimeriidae, Rio de Janeiro.

\section{RESUMO}

O objetivo deste estudo foi caracterizar os oocistos de Eimeria bateri e avaliar o efeito da aflatoxina na morfometria destes oocistos em codornas japonesas naturalmente infectadas. Cin-

* Supported by REUNI, CAPES and CNPq.

${ }^{1}$ Curso de Pós-Graduação em Ciências Veterinárias, Universidade Federal Rural do Rio de Janeiro (UFRRJ), BR 465, km 7, Seropédica, RJ 23890 000, Brasil. Bolsista REUNI. E-mail: bertobp@ufrrj.br

${ }^{2}$ Curso de Pós-Graduação em Patologia, Hospital Universitário Antônio Pedro, Centro de Ciências Médicas, Universidade Federal Fluminense (UFF), Rua Marquês do Paraná, 303, Niterói, RJ 24033-900, Brasil Bolsista CAPES. E-mail: sergian@ufrrj.br

${ }^{3}$ Departamento de Parasitologia Animal, Instituto de Veterinária, UFRRJ, BR 465, km 7, Seropédica, RJ. Bolsista CNPq. E-mail: leira@ufrrj.br / lopescwg@ufrrj.br

${ }^{4}$ Departamento de Patologia e Clínica Veterinária, Faculdade de Veterinária, UFF, Rua Vital Brasil, 64, Niterói, RJ 24320-340, Brasil. Bolsista CNPq. E-mail: anaferreira@pq.cnpq.br qüenta codornas naturalmente parasitadas por E. bateri foram separadas aleatoriamente em dois grupos com 25 aves cada. Um dos grupos foi intoxicado experimentalmente com aflatoxina, por via oral, na dose de $0,04 \mathrm{mg} / \mathrm{kg}$ de peso vivo. Os dois grupos experimentais eliminaram oocistos de E. bateri nas fezes. Esses oocistos foram de subesféricos a elipsóides, $25,1 \times 18,9 \mu \mathrm{m}$, com parede dupla. A micrópila e o resíduo estavam ausentes, mas um ou vários grânulos polares estavam presentes. Esporocistos ovóides alongados, 12,5 × 7,4 $\mu \mathrm{m}$. Os corpos de Stieda e substieda estavam presentes. O resíduo do esporocisto estava disperso e os esporozoítas apresentaram um núcleo e um corpo refráctil. Os histogramas confirmaram a presença de uma única espécie, E. bateri. A regressão linear comprovou que os oocistos de E. bateri são polimórficos, devido, basicamente, à forma desses oocistos. A morfometria comparativa entre os dois grupos experimentais, demonstrou que a aflatoxina influiu significativamente nos oocistos de E. bateri. 
PALAVRAS-CHAVE: Coccídios, oocistos esporulados, morfometria comparativa, Eimeriidae, Rio de Janeiro.

\section{INTRODUCTION}

The Japanese quail Coturnix japonica is a migratory galliforme of the Phasianidae family, native from East Asia (JOHNSGARD, 1988). It was domesticated in the 13th century, introduced in the Americas and, in Brazil. From that time, they were raised mainly for food, egg production or as laboratory animal (WILLIAMS, 1976).

This species is similar in appearance to the gray common quail, C. coturnix. In captivity, these quail should interbreed and produce fertile hybrids. In their natural habitat, C. japonica and $C$. coturnix have not been found to interbreed in areas where they are sympatric. Although, these two species are considered to be in an intermediate stage of speciation, they still warrant designation as two separate species (JOHNSGARD, 1988).

Coccidiosis associated with genus Eimeria Schneider, 1875 in quails was first reported by Tyzzer (1929), when he described E. dispersa in the bobwhite quail Colinus virginianus. Duszynski and Gutierrez (1981) related some eimerid coccidia of quails from USA. In Brazil, the studies of Teixeira and Lopes (2000), Teixeira and Lopes (2002) and Teixeira et al. (2004) pointed out that the four more commons coccidia from Japanese quails are: E. bateri Bhatia, Pandey and Pande, 1965; E. uzura Tsunoda and Muraki, 1971; E. tsunodai Tsutsumi, 1972; and E. fluminensis Teixeira and Lopes, 2000.

The aflatoxin effect associated to the parasitism by eimerid coccidia in Japanese quails never was tested, but a single study exists which report their effects on the interaction in body weight, organs size and in the oocysts reproductive potential (RAO et al., 1990).

The purpose of this study was to contribute on the morphology of E. bateri sporulated oocysts and to evaluate the aflatoxin effect on the oocysts morphometry.

\section{MATERIAL AND METHODS}

Japanese quails C. japonica, derived from a single breeder located at Municipality of Seropédica, State of Rio de Janeiro, Brazil. Seven day-old quails were transported to the Laboratório de Coccídios e Coccidioses at Universidade Federal Rural do Rio de Janeiro in the same Municipality. Quail chicks were maintained in health conditions in polyethylene boxes. Food and water were given ad libitum.

A total of 50 quails naturally parasitized by $E$. bateri were randomly divided into two groups with 25 birds each: The Group I was composed of 10 day-old quail chicks which aflatoxin, in dose of $0.04 \mathrm{mg} / \mathrm{kg}$ body weight and diluted Soya bean oil, was administered to each one chick orally. Group II consisted of 10 day-old quail chicks also positive to E. bateri, however, in each one chick, was administered Soya bean oil free of aflatoxin.
Fecal samples were collected from all quails in the seven day after aflatoxin administration. These samples were placed in a thin layer $(\sim 5 \mathrm{~mm}) \mathrm{K}_{2} \mathrm{Cr}_{2} \mathrm{O}_{7} 2.5 \%$ solution in Petri plates, and incubated at $23-28^{\circ} \mathrm{C}$ for 10 days or until $70 \%$ of oocysts were sporulated. Oocysts were recovered by flotation in Sheather's sugar solution (sp.g. 1.20) and examined under a light microscope (DUSZYNSKI; WILBER, 1997). Morphological observations and measurements, in $\mu \mathrm{m}$, were performed by using a binocular microscope Carl Zeiss with apochromatic oil immersion objective and ocular micrometer K-15X PZO (Poland). Line drawings were prepared with a binocular microscope Wild M-20 with drawing tube. Pictures were prepared using a digital camera model CD Mavica MVCCD250 Sony ${ }^{\circledR}$. Size ranges are in parenthesis followed by means, standard deviations and shape index (length/width).

Statistical analyses were performed using the software Excel XP (Microsoft Co., Redmond, WA, USA). Student's ttest and histograms were done according to Sampaio (2002) and they represented the width, length and shape-index values of the sporulated oocysts and their respective frequencies.

\section{RESULTS}

The Japanese quails shed in their feces hundreds of oocysts of a single species. Initially, were unsporulated; by day four, $70 \%$ were sporulated. This species was described by Bhatia et al. (1965) previously, and re-described by Shah and Johnson (1971) as E. bateri.

Eimeria bateri Bhatia, Pandey and Pande, 1965

Description: Oocysts (Figures 1a, b) subspherical to ellipsoidal, $25.1 \pm 2.3(21-30) \times 18.9 \pm 1.4 \mu \mathrm{m}(15-22)$. Shapeindex of $1.3 \pm 0.1$ (1.1-1.7). Bi-layered wall $\sim 1.1 \mu \mathrm{m}$, smooth. Micropyle and residuum are absent, but one or more polar granules are present. Sporocysts elongate ovoid, $12.5 \pm 0.7$ (11-14) $\times 7.4 \pm 0.6 \mu \mathrm{m}$ (6-9). Shape-index of $1.7 \pm 0.1$ (1.51.9). Stieda body is nipple-like, $\sim 0.7$ high $x 1.1 \mu \mathrm{m}$ wide. The

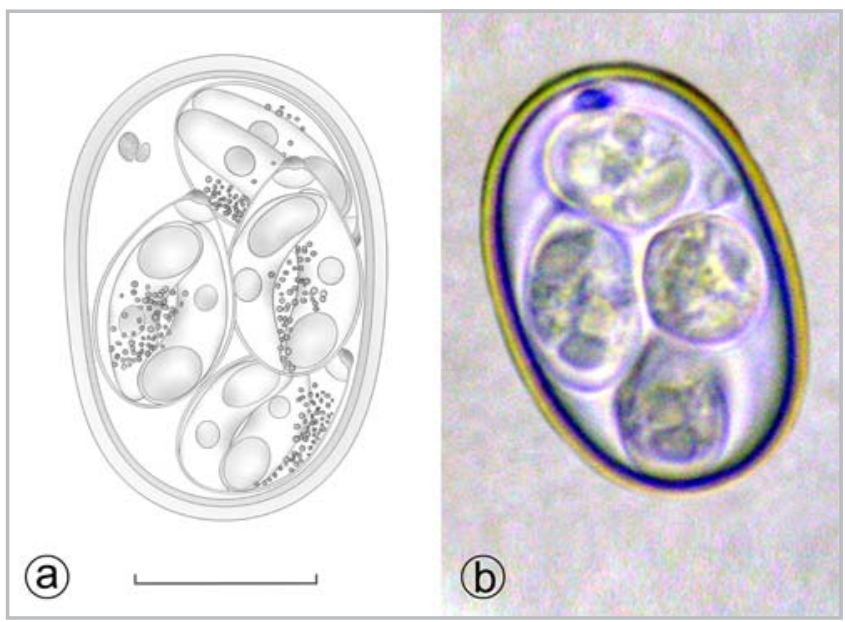

Figure 1. Sporulated oocyst of Eimeria bateri recovered from feces of the Japanese quail Coturnix japonica. Scale bar $=10 \mu \mathrm{m}$. a) Line drawing; b) Photograph. 

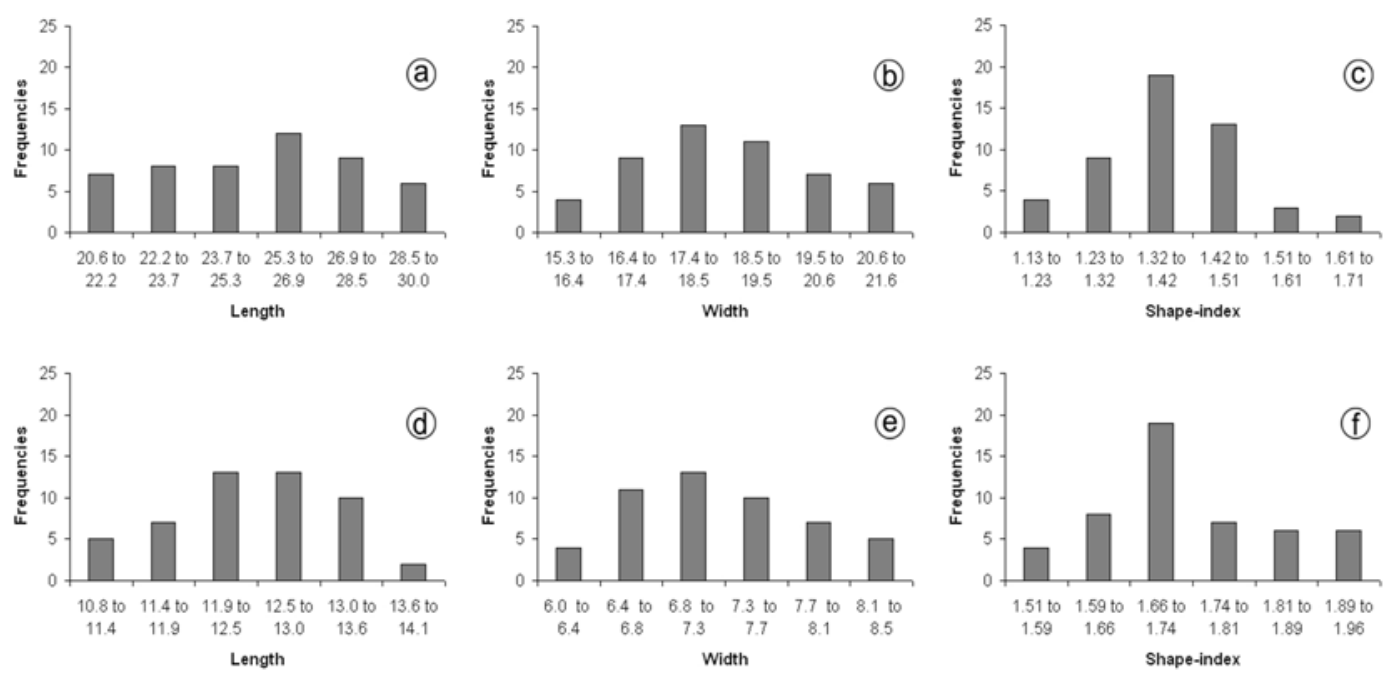

Figure 2. Frequencies in the distribution of the sporulated oocysts of Eimeria bateri recovered from feces of the Japanese quails Coturnix japonica orally administered with aflatoxin in dose of $0.04 \mathrm{mg} / \mathrm{kg}$ body weight. a) Length, b) Width and c) Shape-index of the oocysts; d) Length, e) Width and f) Shape-index of the sporocysts.
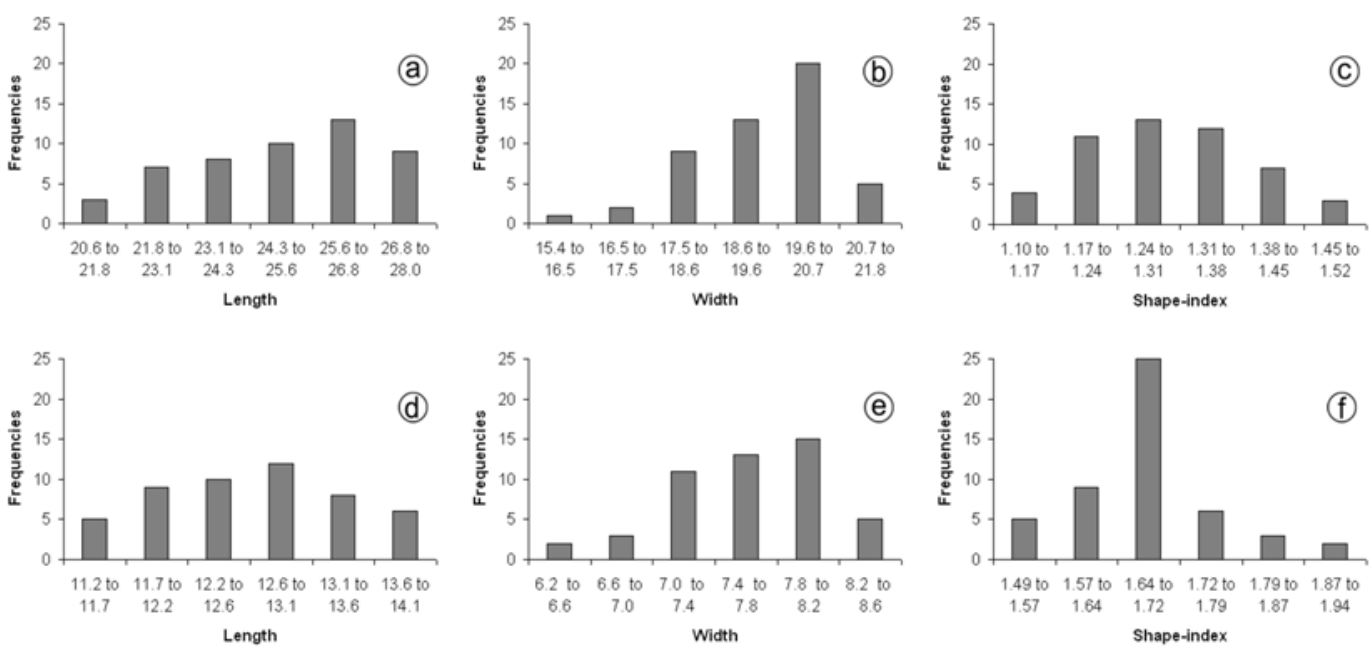

Figure 3. Frequencies in the distribution of the sporulated oocysts of Eimeria bateri recovered from feces of the Japanese quails Coturnix japonica free of aflatoxin. a) Length, b) Width and c) Shape-index of the oocysts; d) Length, e) Width and f) Shape-index of the sporocysts.

substieda body is prominent, $\sim 1.1$ high $\times 2.0 \mu \mathrm{m}$ wide. Sporocyst residuum dispersed and composed of granular material. Sporozoites with a central nucleus and a robust refractile body at one end.

Type host: Coturnix japonica Temminck and Schlegel, 1849 (Galliformes: Phasianidae).

Type locality: Rio de Janeiro, Brazil.

Type material: Oocysts in $10 \%$ aqueous (v/v) buffered formalin deposited at the Parasitology Collection, in the Department of Animal Parasitology, UFRRJ, Seropédica, Rio de Janeiro, Brazil. Repository number is $06 / 2008$, including phototypes and line drawings.

One hundred oocysts of E. bateri were measured. Fifty sporulated oocysts from Group I, as well as 50 from Group II.

In Figures 2 and 3 are presented length, width and shapeindex values of the oocysts and sporocysts, and their respective
Table 1. Comparative morphometry of the oocysts of Eimeria bateri recovered from feces of the Japanese quails Coturnix japonica.

\begin{tabular}{|c|c|c|c|c|c|c|}
\hline \multirow[t]{3}{*}{ Values } & \multicolumn{6}{|c|}{ Sporulated oocysts } \\
\hline & \multicolumn{2}{|c|}{ Length } & \multicolumn{2}{|c|}{ Width } & \multicolumn{2}{|c|}{ Shape-index } \\
\hline & Group I ${ }^{1}$ & Group II ${ }^{2}$ & Group I & Group II & Group I & Group II \\
\hline Mean & 24,9 & 25,3 & 19,3 & 18,4 & 1,3 & 1,4 \\
\hline Variance & 4,15 & 6,70 & 1,44 & 2,38 & 0,01 & 0,01 \\
\hline $\mathrm{n}$ & \multicolumn{2}{|c|}{50} & \multicolumn{2}{|c|}{50} & \multicolumn{2}{|c|}{50} \\
\hline $\begin{array}{c}\text { Group } \\
\text { variance }\end{array}$ & \multicolumn{2}{|c|}{5,42} & \multicolumn{2}{|c|}{1,91} & \multicolumn{2}{|c|}{0,01} \\
\hline $\begin{array}{l}\text { Degrees of } \\
\text { freedom }\end{array}$ & \multicolumn{2}{|c|}{98} & \multicolumn{2}{|c|}{98} & \multicolumn{2}{|c|}{98} \\
\hline$P$ value & \multicolumn{2}{|c|}{0,201784} & \multicolumn{2}{|c|}{0,000672} & \multicolumn{2}{|c|}{0,000033} \\
\hline
\end{tabular}

${ }^{1}$ Samples from free quails of aflatoxin.

${ }^{2}$ Samples from quails orally administered with aflatoxin orally in dose of $0.04 \mathrm{mg} / \mathrm{kg}$ body weight. 
Table 2. Comparative morphometry of the sporocysts of Eimeria bateri recovered from feces of the Japanese quails Coturnix japonica.

\begin{tabular}{|c|c|c|c|c|c|c|}
\hline \multirow[t]{3}{*}{ Values } & \multicolumn{6}{|c|}{ Sporocysts } \\
\hline & \multicolumn{2}{|c|}{ Length } & \multicolumn{2}{|c|}{ Width } & \multicolumn{2}{|c|}{ Shape-index } \\
\hline & Group I' & Group II ${ }^{2}$ & Group I & Group II & Group I & Group II \\
\hline Mean & 12,6 & 12,4 & 7,5 & 7,2 & 1,7 & 1,7 \\
\hline Variance & 0,51 & 0,60 & 0,25 & 0,41 & 0,01 & 0,01 \\
\hline$n$ & \multicolumn{2}{|c|}{50} & \multicolumn{2}{|c|}{50} & \multicolumn{2}{|c|}{50} \\
\hline $\begin{array}{c}\text { Group } \\
\text { variance }\end{array}$ & \multicolumn{2}{|c|}{0,55} & \multicolumn{2}{|c|}{0,33} & \multicolumn{2}{|c|}{0,01} \\
\hline $\begin{array}{l}\text { Degrees of } \\
\text { freedom }\end{array}$ & \multicolumn{2}{|c|}{98} & \multicolumn{2}{|c|}{98} & \multicolumn{2}{|c|}{98} \\
\hline $\mathrm{P}$ value & \multicolumn{2}{|c|}{0,075883} & \multicolumn{2}{|c|}{0,001485} & \multicolumn{2}{|c|}{0,003283} \\
\hline
\end{tabular}

${ }^{1}$ Samples from free aflatoxin quails.

2Samples from quails orally administered aflatoxin orally in dose of $0.04 \mathrm{mg} / \mathrm{kg}$ body weight.Length and shape-index are equivalents, but width is not.

frequencies, according to experimental groups. Frequencies of the oocysts and sporocysts measurements increase and diminish gradually in both experimental groups.

Significant differences were observed on width and shapeindex of sporulated oocysts in the comparative morphometry between experimental groups (Tables 1 and 2).

\section{DISCUSSION}

Oocysts of E. bateri recovered in this study were similarly to those recovered in the studies of Bhatia, Pandey and Pande (1965) and Shah and Johnson (1971). These last authors pointed out that the variation of the oocysts shape varied from spherical to widely ellipsoidal. In this study, these results were confirmed, once what the shape-index of the oocysts ranging from 1.1 to 1.7 .

Still in the study of Shah and Johnson (1971) was described, in the sporocysts, the presence of a hyaline mass dependent of the Stieda body. In the present study, this characteristic was confirmed, measured and described as a substieda body.

Oocysts and sporocysts measurements in both experimental groups were uniforms in their distribution, evidencing the presence of a single species as E. bateri. The significant differences between width and shape-index of sporulated oocysts from experimental groups can be marked also in histograms. The frequency peak of the width histogram of the Group I was observed at 17.4 to $18.5 \mu \mathrm{m}$, whereas, the frequency peak of the width histogram of the Group II was observed at 19.6 to $20.7 \mu \mathrm{m}$. Differences between shapeindexes were resulted from variations in the oocysts widths. In this way, was concluded that aflatoxin interfered in the size, and consequently in the shape, of the sporulated oocysts.

Finally, sporulated oocysts of a single species, E. bateri, were identified in Japanese quails C. japonica and a true substieda body was described at $E$. bateri sporocysts, because was not described previously by Bhatia et al. (1965) and Shah and Johnson (1971). In addition to it, aflatoxin sub-lethal doses given to Japanese quails interfered in the morphometry of the sporulated oocysts.

\section{REFERENCES}

BHATIA, B.B.; PANDEY, T.P.; PANDE, B.P. Eimeria bateri n. sp. from Indian common grey quail (Coturnix coturnix coturnix). Indian Journal of Microbiology, v. 5, n. 1, p. 6164, 1965.

DUSZYNSKI, D. W.; WILBER, P.G. A guideline for the preparation of species descriptions in the Eimeriidae. Journal of Parasitology, v. 83, n. 2, p. 333-336, 1997.

DUSZYNSKI, D.W.; GUTIERREZ, R.J. The coccidia of quail in the United States. Journal of Wildlife Diseases, v. 17, n. 3, p. 371-380, 1981.

JOHNSGARD, P. The Quails, Partridges, and Francolins of the World. Oxford: Oxford University Press. 1988. 288p.

RAO, J.R.; SHARMA, N. N.; IYER, P.K.R.; SHARMA, A.K. Interaction between Eimeria uzura infection and aflatoxicosis in Japanese quail (Coturnix coturnix japonica). Veterinary Parasitology, v. 35, n. 3, p. 259-267, 1990.

SAMPAIO, I.B.M. Estatística aplicada à experimentação animal. $3^{\text {a }}$ ed. Belo Horizonte: FEPMVZ-Editora, 2007. $264 \mathrm{p}$.

SHAH, H.L.; JOHNSON, C.A. Eimeria bateri Bhatia, Pandey and Pande, 1965 from the Hungarian quail Coturnix c. coturnix in the United States and its attempted transmission to the chicken. Journal of Protozoology, v. 18, n. 2, p. 219220, 1971.

TEIXEIRA, M.; LOPES, C.W.G. Eimeria minima n. sp. (Apicomplexa: Eimeriidae) from the Japanese quail (Coturnix coturnix japonica) in Brazil. Revista Brasileira de Ciência Veterinária, v. 7, n. 3, p. 157-158, 2000.

TEIXEIRA, M.; LOPES, C.W.G. Species of the genus Eimeria (Apicomplexa: Eimeriidae) from Japanese quails (Coturnix japonica) in Brazil and E. fluminensis for the preoccupied E. minima of this quail. Revista Brasileira de Ciência Veterinária, v. 9, n. 1, p. 53-56, 2002.

TEIXEIRA, M.; TEIXEIRA-FILHO W.L.; LOPES, C.W.G. Coccidiosis in japanese quails (Coturnix japonica): characterization of a naturally occurring infection in a commercial rearing farm. Revista Brasileira de Ciência Avícola, v. 6, n. 2, p. 129-134, 2004.

TYZZER, E.E. Coccidiosis in gallinaceous birds. American Journal of Hygiene, v. 10, p. 269-383, 1929.

WILLIAMS, C.S.F. Practical Guide to Laboratory Animals. Saint Louis: CV Mosby Company, 1976. 207p.

Received on September 23, 2008.

Accepted for publication on December 29, 2008. 